Ines Carović

Ana Vidović

Mirjana Mateja Kovač

\title{
USPOREDBA GOVORNIH POGREŠAKA U HRVATSKOME KAO STRANOM JEZIKU IZMEĐU POČETNIH I NAPREDNIH STUPNJEVA UČENJA
}

\section{Sažetak}

Cilj rada je istražiti sličnosti $i$ razlike u procesiranju govora na hrvatskome kao stranome jeziku (J2) s obzirom na različit stupanj usvojenosti jezičnoga koda - početni i napredni. Procesiranju se pristupilo analizirajući govorne pogreške koje su jedna od njegovih najneposrednijih vanjskih manifestacija. Analizirane su varijable govorne fluentnosti: gramatičke pogreške, oklijevanja $i$ samoispravci, te se nastojalo objasniti što te pojave otkrivaju o psiholingvističkim procesima govorne proizvodnje u J1 i J2. U ispitivanju je sudjelovalo deset govornika engleskoga kao materinskoga jezika koji su institucionalizirano učili hrvatski četiri mjeseca u Croaticumu - centru za hrvatski kao drugi i strani jezik na Filozofskom fakultetu u Zagrebu. Podijeljeni su u dvije skupine prema usvojenosti, odnosno stupnju učenja hrvatskoga, a homogeni su sobzirom na isti materinski jezik. Ispitivanje je potvrdilo obje postavljene hipoteze: da govornici početnog $i$ naprednog stupnja učenja hrvatskog kao stranog jezika čine različite vrste govornih pogrešaka te da se govornici početnog $i$ naprednog stupnja učenja hrvatskog kao stranog jezika razlikuju u ukupnom broju govornih pogrešaka.

Ključne riječi: govorne pogreške, učenje jezika, strani jezik, hrvatski jezik

\section{UVOD}

Govorne pogreške su odstupanja od govornikovih komunikacijskih namjera do kojih dolazi tijekom govorne proizvodnje, a mogu zahvatiti sve njezine razine: misaonu, jezičnu i govornu razinu (Horga, 1997). Važan su pokazatelj mehanizama koji su u osnovi jezičnog planiranja i formuliranja govornog iskaza. Naime, za vrijeme izvođenja jedne sastavnice, govornik planira izvođenje sljedeće. Ta neprestana izmjena planiranja i izvođenja može narušiti tečnost i prouzročiti govorne pogreške (Horga, 1996).

Govorne pogreške mogu se pojaviti u različitim oblicima, o čemu ovisi i način njihove klasifikacije.

Jednu skupinu govornih pogrešaka čine odstupanja na nekoj od jezičnih razina: fonološkoj (kojima pripadaju i anticipacije, supstitucije i sl.), morfološkoj, leksičkoj ili sintaktičkoj. 
U nekim je slučajevima "čista" kategorizacija neostvariva, jer se npr. odstupanje na fonološkoj razini istovremeno može promatrati kao odstupanje na morfološkoj i/ili leksičkoj razini. U drugu skupinu pogrešaka spadaju raznovrsni oblici oklijevanja kojima govornik "kupuje vrijeme" potrebno za oblikovanje poruke koju je želio prenijeti i daje signal sugovorniku da još nije završio svoj iskaz te se "brani" da mu ne "preuzme riječ" (Horga, 1996). Razlozi za oklijevanje mogu biti: nemogućnost pronalaženja pravog podatka, nemogućnost pronalaženja prave riječi, odluka da se poruka želi oblikovati na drugačiji način, bilo ubacivanjem novog podatka, bilo izbacivanjem već postojećeg, promjenom redoslijeda elemenata unutar iskaza. U oklijevanja se ubrajaju prazne stanke koje nisu dio strukture prirodnoga govora, dakle nisu posljedica logičke organizacije poruke ili bioloških zahtjeva za udahom, već se percipiraju kao disfluentnost, nefonemski odsječci, poštapalice, produživanja vokala ili drugog "produživog" glasnika (npr. frikativa), duže prazne stanke ili ponavljanja (Horga, 1996, 1997).

Psiholingvistima su posebno zanimljiv oblik govornih disfluentnosti takozvani samoispravci, slučajevi govornikova samoinicijativnoga prekida na nekom dijelu strukture iskaza kako bi se ispravio. Samoispravci su potvrda postojanja govornikova unutarnjeg mehanizma samonadzora vlastita govora koji mu omogućuje da pogrešku uoči, a zatim i ispravi (Horga, 1997).

Govorne samoispravke sustavno je istraživao Levelt (1983) prema kojemu tipični samoispravak sadrži tri dijela: 1. izvorni iskaz koji uključuje dio od početka posljednje rečenice prije reparanduma (dijela iskaza koji treba ispraviti, a može biti različite veličine, od jednoga glasa do čitava teksta) do trenutka prekida; 2. kraći ili duži period oklijevanja; 3 . ispravak. Treba naglasiti da se u mnogo popravaka ne ispravlja nešto pogrešno, ili pogreška barem nije površinski primjetljiva, tj. slušatelj je ne uspijeva percipirati. Također, neki ispravci i sami nisu ispravni te vode do dodatnih ispravaka.

Samoispravak se može dogoditi u bilo kojem dijelu govorne proizvodnje: pri generiranju poruke, njezinu formuliranju koje uključuje leksikalizaciju ili prizivanje i odabir lema, stvaranju funkcionalnog okvira za odabrane leksičke jedinice, stvaranju morfološkog okvira te fonetskog kodiranja iskaza, i konačno, u posljednjoj fazi stvaranja govornoga zvuka (Horga, 1997).

Pogreškom može biti zahvaćen i tzv. monitoring ili "govorni promatrač" (Horga, 1997) koji uspoređuje ostvarenu poruku s onom koju je govornik namjeravao poslati.

Levelt (1983, 1989), s obzirom na razinu na kojoj je pogreška počinjena, razlikuje sljedeće vrste samoispravaka:

1. Drukčija obavijest kojom se mijenja prvotna obavijest. U tijeku govora govornik može promijeniti svoje mišljenje i shvatiti da je bolje da pošalje drugu poruku, a ne onu koju upravo oblikuje. Često je prisutna u izražavanju složene tvrdnje. Važno je odlučiti što reći prvo, a što će tu tvrdnju slijediti, kao u primjeru' "Kreni Ilicom od glavnoga trga, zatim kreni ... ne, dođi do glavnog kolodvora,

\footnotetext{
${ }^{1}$ Svi primjeri su preuzeti iz transkribiranih tekstova iz ovoga istraživanja.
} 
produži do glavnoga trga, zatim kreni Ilicom od glavnoga trga prema Frankopanskoj."

2. Ispravci kojima se prvotni izraz zamjenjuje prikladnijim izrazom, što će se dogoditi ako:

a) je prvotni izraz dvosmislen: npr. "Djevojčica ju je počastila tortom ... svoju prijateljicu je počastila tortom."

b) prvotni izraz nije dovoljno precizan, kao u primjeru: "Sada moram ispričati priču o djetetu ... ə o djevojčici."

c) prvotni izraz nije u skladu s prethodno upotrijebljenima, npr. "Mala je, djevojčica je sve lijepo počistila", gdje izraz mala nije u skladu sa standardnim izrazom biranim u opisu. Ovu je podskupinu Kormos (1998) dalje izdiferencirala dodavši i tzv. samoispravke u svrhu "uglađena" jezika, koji su češći na višim razinama ovladanosti stranim jezikom, kada se izraz nastoji i stilistički dotjerati. Primjer je zamjena riječi osoba riječju ljudi jer je riječ osoba prethodno već nekoliko puta upotrijebljena (primjer prema Kormos, 1998).

U svojoj primjeni Leveltove klasifikacije na klasifikaciju pogrešaka u drugome jeziku, Kormos (1998) ovoj skupini nadodaje i četvrtu podskupinu - samoispravci pragmatički neprikladnih izraza, kada se izraz prilagodi kontekstu u kojemu se upotrebljava. Tako je u rečenici "Donesi mi... možeš li mi donijeti ugovor", imperativ dodaj mi, zamijenjen pitanjem možěs li mi donijeti, u skladu sa zahtjevima poslovne komunikacije.

3. Samoispravci koji se prema Leveltu (1983) odnose na zamjenu pogrešnog fonema, riječi ili sintaktičke konstrukcije ispravnim oblicima.

Prema tome, razlikujemo:

a) leksičke samoispravke, koji uključuju zamjenu bilo koje leksičke jedinice: prijedloga, veznika, imenice, glagola i dr. drugom leksičkom jedinicom, npr. "Navečer gleda HTV-ov Vjesnik ... Dnevnik."

b) sintaktičke samoispravke, koji nastupaju ako sintaktička konstrukcija vodi do "mrtve točke" i ne može se nastaviti, npr. "Oni imaju a: njihov a: oni idu na putovanje."

c) fonološke samoispravke, kojima se ispravlja pogrešna fonološka jedinica, npr. "Krene na posao u setam, sedam sati."

4. Posljednja skupina samoispravaka prema Leveltovoj klasifikaciji jesu takozvani prikriveni popravci u kojima nema opažajnih pogrešaka ili odstupanja, a ostvaruju se na dva načina:

a) kao prekid, s nekim oblikom oklijevanja ili bez oklijevanja: "Krenula je uuu (stanka) sedam sati."

b) kao ponavljanje jedne ili više jezičnih jedinica koje nisu pogrešne: "Krenula je u sedam, u sedam sati." 
Horga (1997) razlikuje i sljedeće oblike samoispravaka, od kojih se neki u većem ili manjem opsegu preklapaju s Leveltovom klasifikacijom:

1. Ubacivanje zaboravljenog podatka u iskaz, kao u primjeru: "Puhnula je u svjećice... pozvala je prijatelje i puhnula je u svjećice..."

2. Anticipacijsko srljanje pri kojemu govornik anticipira dio budućeg govornog programa, ali ga naglo prekida jer je ispustio dio obavijesti npr. "Kupio je plav... bijelu majicu s plavim natpisom."

3. Traženje pravog podatka koje je, za razliku od uporabe pogrešne riječi kao posljedica nefunkcioniranja jezične razine, odraz poteškoća na konceptualnoj razini jezične proizvodnje, npr. "Na torti je dva, četiri, sedam svjećica."

4. Odbacivanje suvišnoga kao u primjeru: "Igrali su se dječjim lut, igrali su se lutkama."

Govorne pogreške nisu samo zanimljive u promatranju govora na prvome, materinskome jeziku, nego osiguravaju neposredan pristup i mentalnome procesiranju drugoga jezika. Polazište su i za usporedbu tih procesa u materinskome (J1) i drugome (J2) jeziku, ali i pri različitim stupnjevima usvojenosti drugoga jezika.

Kao što i u usvajanju materinskoga jezika postoje univerzalna načela i zakonitosti te sustavne razvojne faze, tako i u učenju drugoga jezika prepoznajemo neke sustavne odrednice i pravilnosti (Jelaska, 2005).

Analiza govornih pogrešaka mogla bi dati odgovore na pitanja: kako su povezane razine jezične proizvodnje na višoj i nižoj razini usvojenosti nekoga jezika, uključuje li razlika u procesiranju jednu ili više razina, kako su te razine u ovim dvama slučajevima povezane, koje su ključne razlike u obradi jezičnih jedinica, je li leksički pristup osoba koje su različito usvojile neki jezik jednak ili se razlikuje, te općenito, na koji se način u različitim govorno-jezičnim fazama u J2 ostvaruje i organizira komunikacija.

\section{CILJ I HIPOTEZE}

Cilj rada bio je istražiti sličnosti i razlike u procesiranju govora na hrvatskome kao stranome jeziku (J2) s obzirom na različit stupanj usvojenosti jezičnoga koda početni i napredni. Procesiranju se pristupilo analizirajući govorne pogreške koje su jedna od njegovih najneposrednijih vanjskih manifestacija. Postavljene su sljedeće hipoteze:

1) Govornici početnog i naprednog stupnja učenja hrvatskog kao stranog jezika činit će različite vrste govornih pogrešaka, što ovisi o različitim psiholingvističkim mehanizmima kojima pristupaju hrvatskome jeziku.

2) Govornici početnog i naprednog stupnja učenja hrvatskog kao stranog jezika razlikovat će se u ukupnom broju govornih grešaka. 


\section{MATERIJALI I METODE}

Ispitanici su bili studenti Croaticuma - centra za hrvatski kao drugi i strani jezik na Filozofskom fakultetu u Zagrebu, deset govornika engleskoga kao materinskoga jezika koji su institucionalizirano učili hrvatski četiri mjeseca. Ispitanici su podijeljeni u dvije skupine prema usvojenosti, odnosno stupnju učenja hrvatskoga (četiri početnika i šest naprednih). U ispitivanjima je teško kontrolirati sve varijable te je sličnost jezičnih kategorija bio najvažniji kriterij, dok se izvanjezični kriteriji kao što su dob, obrazovanost, zanimanje i koliko vremena osoba živi u Hrvatskoj te koliko jezika i koje jezike govori i slično teško kontroliraju te nisu uzimani kao varijable u ovom istraživanju. Podijeljeni su u dvije skupine, početnici su bili na višoj početnoj razini znanja jezika 1B (prema CEF-u A2), a napredni su barem kratko, u dobi do šeste godine, pasivno slušali hrvatski, te su bili na višoj srednjoj razini učenja $2 \mathrm{~B}$ (prema CEF-u B2). Ispitanici su imali zadatak opisati tri slike, dvije koje opisuju radnje kroz dan, i treću koja prikazuje sobu (primjeri u prilogu 2, 3,4). Ispitanici su snimani individualno u studijskim uvjetima. Snimke su transkribirane te su analizirani oblici disfluentnosti, odnosno oblici prekida tečnosti govora što se može vidjeti na primjeru govora početnika i naprednih u prilogu 1. Analizirane su varijable govorne fluentnosti: gramatičke pogreške (fonološke, morfološke, leksičke, sintaktičke), oklijevanja (nefonemski segment, prazne stanke, poštapalice, ponavljanja, produživanja glasnika), samoispravci (ubacivanje zaboravljenog, anticipacijsko srljanje, traženje pravog podatka, zamjena za prikladniji izraz, samoispravci gramatičkih pogrešaka, prikriveni popravci, parafraziranje) i prekid. Analizirano je i trajanje opisa u sekundama te ukupan broj slogova u opisu, tempo govora (broj slogova u sekundi) i period tečnosti (prosječno trajanje tečnoga govora od jednog do drugoga prekida govora). Analiza je provedena u programu Cool Edit Pro 2.1, a rezultati su obrađeni i analizirani programom Excel.

\section{REZULTATI I RASPRAVA}

Rezultati analize, očekivano, pokazuju da početna skupina u učenju hrvatskoga kao drugog jezika ostvaruje mnogo više različitih oblika disfluentnosti od napredne skupine, čime je potvrđena druga hipoteza.

Tablica 1. Ukupna disfluentnost u objema skupinama

Table 1. Disfluency rate in both groups of subjects

\begin{tabular}{|l|c|c|}
\hline Skupina & Početnici & Napredni \\
\hline Ukupno disfluentnosti & $65 \%$ & $35 \%$ \\
\hline
\end{tabular}


Rezultati potvrđuju pretpostavku da će govornici u različitim govornim situacijama griješiti u različitim omjerima. Na govornu fluentnost utječe opće stanje govornika, količina stresa, razina pripremljenosti, posebice u javnome govorenju, no jedan od važnijih faktora upravo je stupanj ovladanosti jezičnim kodom. Dakle, ako govornici nisu sigurni u znanje stranoga jezika te ga nisu do kraja automatizirali, griješit će više i češće.

Tablica 2. Vremenska obilježja za početnu i naprednu skupinu

Table 2. Temporal characteristics in beginners and advanced learners

\begin{tabular}{|l|r|r|}
\hline & Početnici & Napredni \\
\hline Trajanje opisa (s) & 106,08 & 78,21 \\
\hline Broj slogova u opisu & 198,42 & 244,44 \\
\hline Tempo govora (slog/s) & 1,92 & 3,20 \\
\hline Period tečnosti (s) & 1,77 & 2,42 \\
\hline
\end{tabular}

Za isti slikovni predložak početnicima treba mnogo više vremena da ga opišu nego naprednima. Tako je prosječno vrijeme trajanja opisa početnika $106,08 \mathrm{~s}$ za ukupno izgovorenih prosječno 198 slogova, a naprednih 78,21 s za količinu od 244 izgovorena sloga. Ovi podaci upućuju da pretvorba misli i koncepata u strukturiranu jezičnu cjelinu zahtijeva više vremena ako jezik nije dovoljno usvojen.

Relevantne kategorije analizirane su t-testom i dobiveni su podaci koji ukazuju na statistički značajnu razliku za sve kategorije osim za samoispravke koji bi mogli pokazivati kako nedostatak samokontrole, odnosno prenizak stupanj usvojenosti hrvatskoga tako i nedostatak kritičnosti prema vlastitom (pogrešnom) govoru.

Tablica 3. t-test istraživanih kategorija (tempo govora, period tečnosti i oblici disfluentnosti)

Table 3. Degree of difference between variables (speech rate, fluency period and disfluency type)

\begin{tabular}{|l|c|}
\hline \multicolumn{1}{|c|}{ Kategorije } & $\mathrm{p}$ \\
\hline Tempo govora (slog/s) & 0,000 \\
\hline Period tečnosti (s) & 0,007 \\
\hline Oblici disfluentnosti - ukupno (broj/min) & 0,010 \\
\hline Gramatičke pogreške (broj/min) & 0,011 \\
\hline Oklijevanja (broj/min) & 0,032 \\
\hline Samoispravci (broj/min) & 0,775 \\
\hline
\end{tabular}




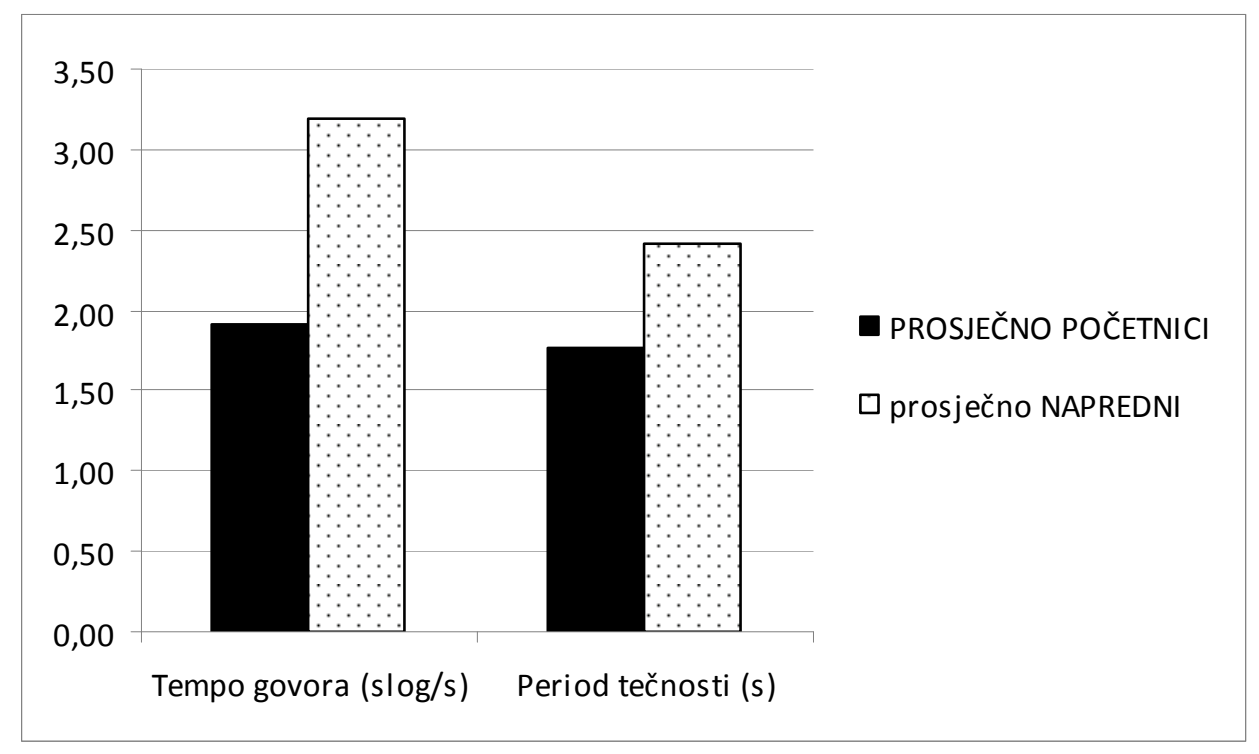

Slika 1. Tempo govora i period tečnosti za početnu i naprednu skupinu Figure 1. Speech arte and fluency period in beginners and advanced learners

Jedan od važnih pokazatelja govorne fluentnosti je i tempo govora, tj. broj izgovorenih slogova u sekundi (Horga i Požgaj Hadži, 2004). U početnika je tempo govora manje vrijednosti $(1,92)$ u odnosu na naprednu skupinu čiji tempo govora iznosi 3,20 čime se također napredni približavaju tempu govora izvornih hrvatskih govornika (u usporedbi s kontrolnom skupinom izvornih govornika čiji je tempo govora 3,66). Razlika se pokazala statistički značajnom $(\mathrm{p}=0,000)$.

Dobiveni rezultat također potvrđuje da govornicima koji još nisu dovoljno usvojili jezik treba više vremena kako bi procesirali informacije na nekoj od govorno-jezičnih razina proizvodnje govora: bilo u prizivu lema, gramatičkome kodiranju ili pri samoj artikulaciji.

Osim tempa govora, ukupnoj percepciji tečnosti pridonosi i odsječak tečnosti u govornom iskazu između dviju disfluentnih jedinica, što prikazuje period tečnosti. Taj period u početnika iznosi $1,77 \mathrm{~s}$, a u naprednih 2,42 s. Razlika je statistički značajna $(p=0,007)$. To je u skladu s pretpostavkom da će početnici više griješiti, što bi podrazumijevalo da imaju i kraće vrijeme tečnoga govora, odnosno govora bez govornih disfluentnosti. 
Tablica 4. Oblici disfluentnosti u govoru početne i napredne skupine Table 4. Disfluency types in beginners and advanced learners

\begin{tabular}{|l|c|c|}
\hline & $\begin{array}{c}\text { Prosječno } \\
\text { početnici }\end{array}$ & $\begin{array}{c}\text { Prosječno } \\
\text { napredni }\end{array}$ \\
\hline Oblici disfluentnosti - ukupno (broj/min) & 36,72 & 26,64 \\
\hline Gramatičke pogreške (broj/min) & 11,08 & 5,54 \\
\hline Oklijevanja (broj/min) & 20,74 & 15,98 \\
\hline Samoispravci (broj/min) & 4,90 & 5,11 \\
\hline
\end{tabular}

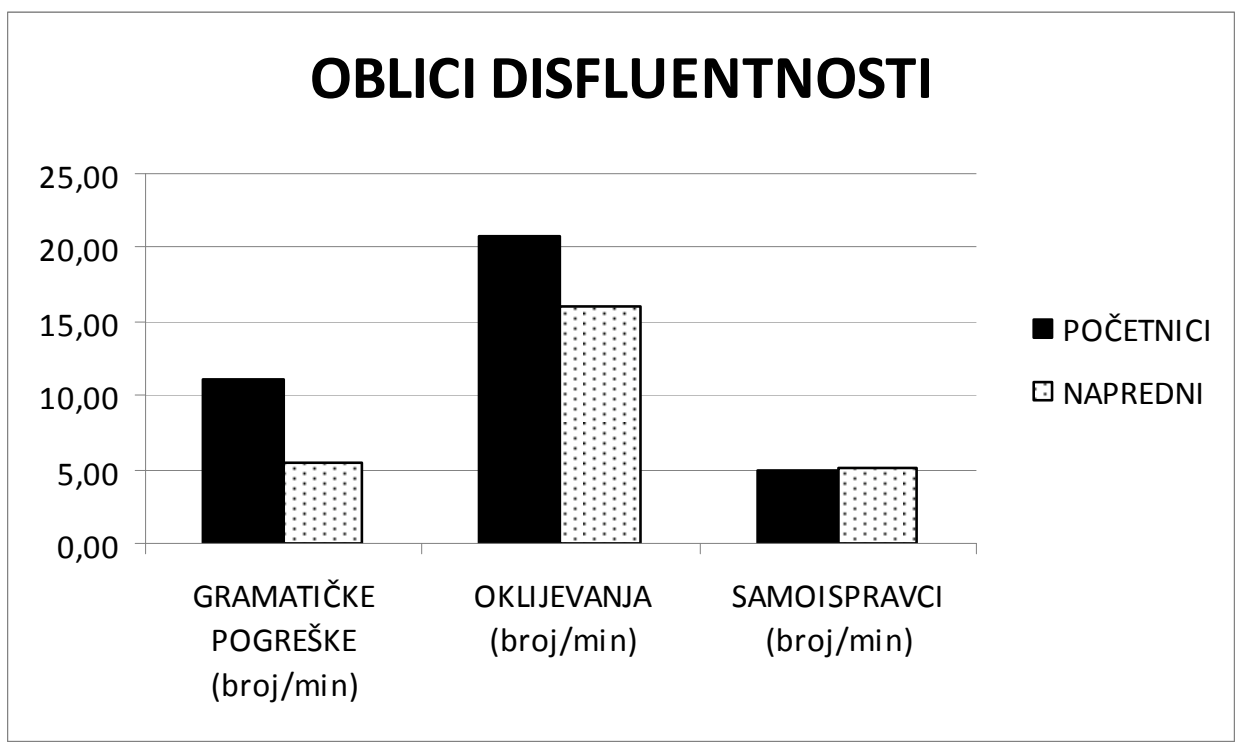

Slika 2. Oblici disfluentnosti

Figure 2. Disfluency types

Gramatičke pogreške, posve očekivano, više čine početnici, 11,08 u minuti, odnosno 30\% ukupnih disfluentnosti, nego napredna skupina sa 5,54 u minuti, odnosno $21 \%$ ukupnih disfluentnosti. Razlika se, pokazala i statistički značajnom $(\mathrm{p}=0,011)$.

Kod početne skupine su od svih gramatičkih pogrešaka najučestalije morfološke pogreške koje čine čak $61,69 \%$ svih gramatičkih pogrešaka budući da se na početnim razinama učenja hrvatskoga inzistira na usvajanju i osvještavanju kategorija kao što su padeži i lica. U početnim fazama učenja kada morfološki sustav još nije usvojen učenici kose oblike nekih imenica smatraju posve drugim riječima. Tome pridonosi i česta gramatička homonimija. Tako će genitiv jednine muškoga roda susjeda početnici često zamijeniti riječju u nominativu jednine ženskoga roda koja ima isti 
izraz. S druge strane, različiti oblici riječi mogu imati bitno različiti izraz, npr. infinitiv brati i 1. lice jednine prezenta berem (Jelaska, 2005).

$\mathrm{Za}$ govornike engleskoga kao materinskoga jezika često dolazi i do određene nelagode zbog tih novih kategorija te sami govornici budu opterećeni gramatičkom točnošću i mnogobrojnošću morfoloških oblika na koje ne moraju paziti u svom materinskom jeziku.

Oklijevanja su učestalija u početnika, ukupno 20,74 u minuti (tablica 4), dok napredna skupina ostvaruje prosječno 15,98 oklijevanja u minuti, što može ukazati na različite oblike procesiranja u J1 i J2. Osim procesiranja u drugom, odnosno stranom jezičnom sustavu na razini fonologije, morfologije, odabira lema u skromnom vokabularu stranoga jezika, oklijevanja su i pokazatelj "psihičke" pripreme za pravilan odabir jezičnih jedinica te koliko je sugovornik siguran u točan izbor. Jedna od funkcija oklijevanja je "kupovanje vremena" za oblikovanje naših misli i uspješno jezično kodiranje bez da se prekine misao. Istovremeno, time signaliziramo sugovorniku da naš iskaz još nismo završili kako nam ne bi "oduzeo riječ". Zato je posve očekivano da, u skladu s već spomenutim tvrdnjama, početnici, koji uporabu stranog jezika još nisu "automatizirali", češće koriste strategije oklijevanja kako bi imali više vremena procesirati informacije na svim razinama i složiti gramatičko-semantički valjan iskaz.

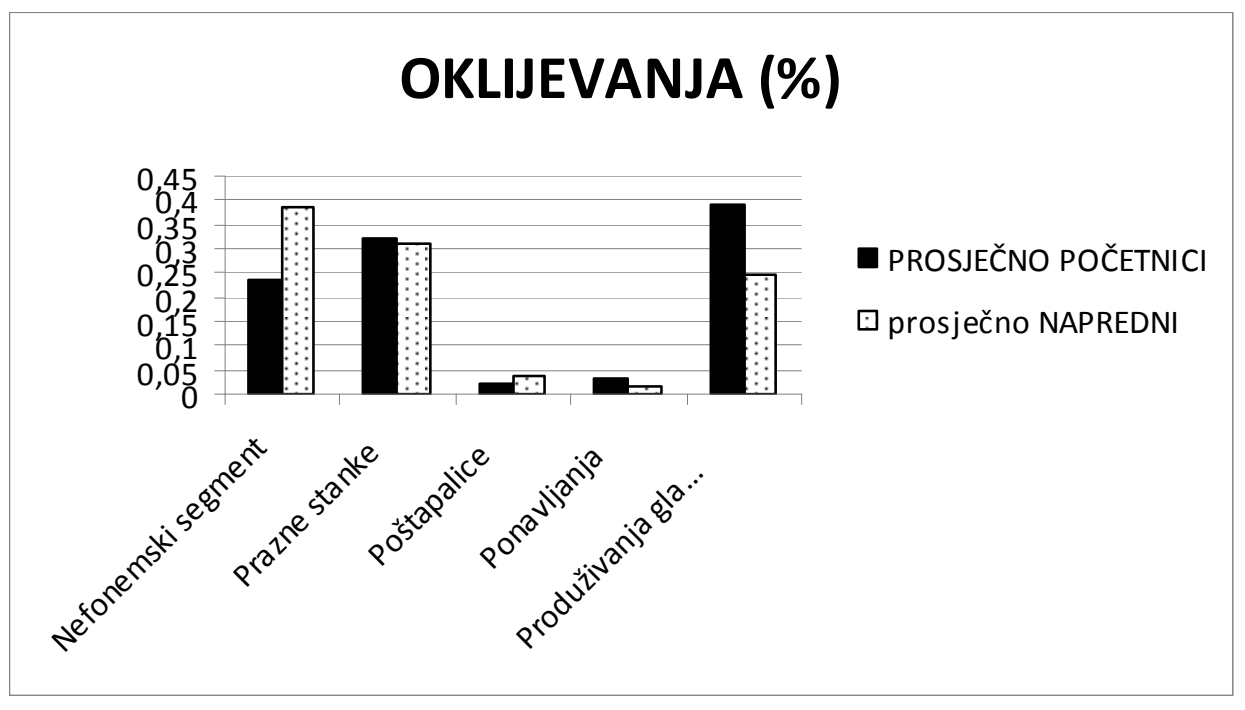

Slika 3. Vrste oklijevanja u početne i napredne skupine Figure 3. Hesitation types in beginners and advanced learners 


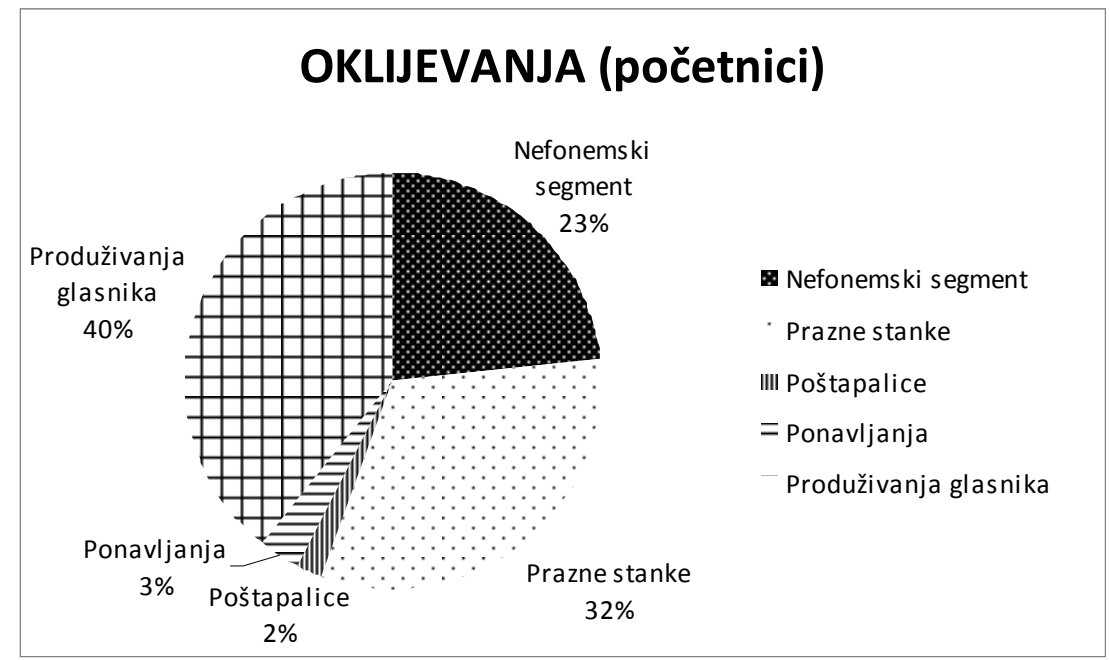

Slika 4. Oklijevanja u početne skupine Figure 4. Hesitations in beginners

Unutar kategorije oklijevanja, početnici najčešće produžuju glasnik (u $40 \%$ svih oklijevanja), a česte su i prazne stanke (32\% svih oklijevanja). Nefonemski segment (od kojih su najčešći poluvokal [ə] ili njegova nosna inačica) čini $23 \%$ ukupnih oklijevanja.

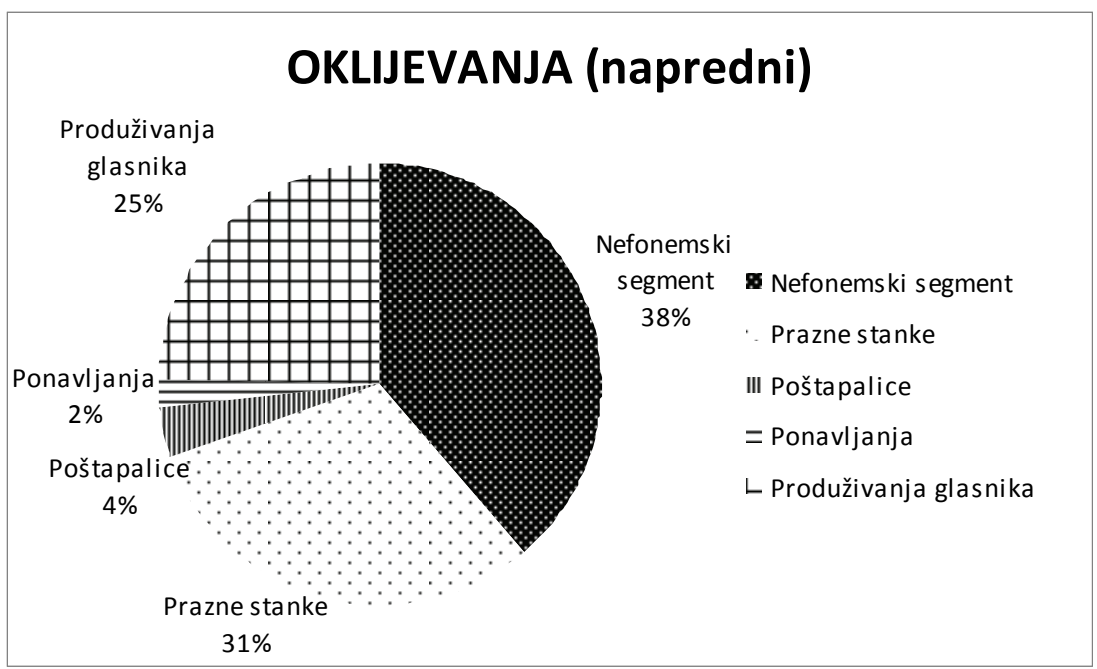

Slika 5. Oklijevanja u napredne skupine

Figure 5. Hesitations in advanced learners 
Najčešća strategija oklijevanja u naprednih je uporaba nefonemskoga segmenta (u $38 \%$ slučajeva), a zatim uporaba praznih stanki (u $31 \%$ slučajeva) te produživanje glasnika (u $25 \%$ slučajeva).

Napredni se najčešće služe nefonemskim segmentom (tzv. zvučnom stankom) ili praznom stankom dok se početnici najčešće kod oklijevanja služe duljenjem glasnika te, podjednako kao i napredni, praznom stankom.

I početnici i napredni upotrebljavali su sve kategorije strategija oklijevanja, a rezultati su slični u naprednih i u izvornih govornika kontrolne skupine što se posebno vidi na najčešćem pribjegavanju nefonemskom segmentu te ukazuje na visok stupanj usvojenosti nekog jezika.

Napredna skupina u prosjeku ostvari između pet i šest samoispravaka u minuti, što pokazuje da je sklonija samoispravljanju od početnika koji u minuti ostvare između četiriju i pet ispravaka. Ipak, razlika se nije pokazala statistički značajnom $(p=0,775)$ što bi se moglo objasniti većom tolerancijom na pogreške, odnosno nižim stupnjem poznavanja jezika što je u ovom slučaju vjerojatnije jer su napredni ispitanici kritičniji i skloniji samoispravljanju. Minimalna razlika u samoispravljanju mogla bi proizlaziti i iz svijesti o uporabnoj normi i gramatičkim pravilima, te bi trebalo pogledati odnos gramatičkih pogrešaka i samoispravljanja koji je veći kod napredne skupine. Iz toga proizlazi da napredna skupina manje griješi, ali se brojčano jednako samoispravlja kao i početnici te bi taj odnos mogao pokazati samokritičnost i veću usvojenost gramatičkog sustava hrvatskoga jezika na višoj razini učenja.

\section{ZAKLJUČAK}

Pokušale su se, na različitim primjerima izgovornih pogrešaka, odnosno na različitim oblicima govorne disfluentnosti, otkriti razlike u procesiranju govora na hrvatskome kao drugome i stranome jeziku. Osim što su sustavno analizirane i klasificirane pogreške na različitim razinama (fonološkoj, morfološkoj, leksičkoj i sintaktičkoj) te su pogreške svrstane u različite kategorije govorne disfluentnosti (gramatičke pogreške i samoispravke) do kojih dolazi na jezičnoj i govornoj razini tijekom proizvodnje govora, te na oklijevanja kao posebnu kategoriju koja direktno upućuje na govornikovu komunikacijsku namjeru na misaonoj razini tijekom govorne proizvodnje.

Kod prosječno većeg broja govornih disfluentnosti u početnika nego u napredne skupine može se potvrditi teza s početka članka o mehanizmima jezičnoga planiranja i formuliranja jezičnoga iskaza kod većeg stupnja usvojenosti drugog ili stranoga jezika (u ovom slučaju kod hrvatskoga). Veći broj govornih disfluentnosti, a posebno najveći udio oklijevanja u tim disfluentnostima u početnika pokazuje i najveće narušavanje tečnosti koje bi se moglo objasniti izmjenom planiranja i izvođenja govornih sastavnica. 
Najveća razlika u vrstama govornih pogrešaka se pokazala kod različitih kategorija oklijevanja. Dok su početnici najviše pribjegavali produživanjima glasnika, napredni su se oklijevanjem pomoću nefonemskoga segmenta služili na gotovo istoj razini kao i kontrolna skupina što pokazuje približavanje jezične usvojenosti na visokoj jezičnoj razini. Ta razlika mogla bi se istražiti i na neurološkoj razini te dati prava objašnjenja uzroka upravo ovih rješenja kojima su pribjegavali naši ispitanici.

Ovo istraživanje samo je mali korak k razumijevanju psiholingvističke obrade komunikacijskih namjera govornika drugoga i stranoga jezika. Rezultati daljnjih istraživanja, kao i veći broj ispitanika pridonijet će otkrivanju novih aspekata ovih procesa.

\section{REFERENCIJE}

Horga, D. (1996). Obrada fonetskih obavijesti. Zagreb: Hrvatsko filološko društvo.

Horga, D. (1997). Samoispravljanje u govornoj proizvodnji. Suvremena lingvistika 19, 91-104.

Horga, D., Požgaj Hadži, V. (2004). Govorna fluentnost u stranom jeziku. Suvremena kretanja u nastavi stranih jezika: zbornik radova sa savjetovanja održanog 17. i 18. svibnja 2002. u Opatiji. Zagreb: Hrvatsko društvo za primijenjenu lingvistiku.

Jelaska, Z. (2005). Hrvatski kao drugi i strani jezik. Zagreb: Hrvatska sveučilišna naklada.

Kormos, J. (1998). A new psycholingvistic taxonomy of self-repairs in L2: A qualitative analysis with retrospection. The Even Yearbook: Working Papers of the Departemnt of Lingusitics. Eötvös Loránd Univerity, 3, 43-68.

Levelt, W. J. M. (1983). Monitronig and self-repair in speech. Cognition 14, 41-104.

Levelt, W. J. M. (1989). Speaking. Fromi intenton to articulation. Cambridge, Massachusetts: MIT Press. 


\section{Prilog 1}

\section{Početnici}

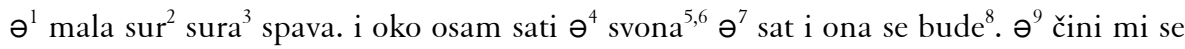
da ona je dosta sretna. $\partial^{10}$ datum je $\partial^{11} \operatorname{sedmog}^{12} \operatorname{srpajn}^{13}$ srpnja i sad ona ${ }^{14}$ mala sura $^{15} \partial^{16}$ brisa ${ }^{17}$ stol i onda sprema stol imaa ${ }^{18} \mathrm{v}^{19} \partial \mathrm{m}^{20}$ imaaa ${ }^{21}$ kako se kaže $e^{22} \ldots{ }^{23} \ni \mathrm{m}^{24}$ lijepu $\mathrm{s}^{24}$ sliku na zidu ii ${ }^{25}$ oko $ə \mathrm{~m}^{26}$ popod $^{27}$ dvanaest i petnaest $ə \mathrm{~m}^{28} \mathrm{oni}^{29}$ je spremna, oni ${ }^{30}$ je sprema nisam vidimo ${ }^{31}$ zato $^{32} . \ominus^{33}$ stiže $^{34}$ dru $^{35}$ neki $^{36} * 37$ neki dečko...

\section{Napredni}

Priča o maloj Luciji. Mala Lucija spava u krevet ${ }^{1}$. Danas je $s^{2}{ }^{2}$ sedmog ${ }^{3,4}$ svibnja iii $^{5}$ danas $\mathrm{je}^{6}{ }^{* 7} \mathrm{n}^{8}$ njezin rođendan. Probudila se u sedam ujutro. Morala je čistiti kuću i pripremiti se zaa ${ }^{9}$ svoju zabavu. $\partial^{10} * 11$ uuu ${ }^{12} \partial^{12}$ napravila je svoj kol ${ }^{13}$ svoje kolače za svih ${ }^{14} \mathrm{i}$ $\partial \mathrm{m}^{15}$ kupila je sedam svijeća za svoj ${ }^{16}$ za svoju tortu. $\mathrm{U}$ tri sata $\partial^{17}$ njezin $\mathrm{i}^{18}$ prijatelji počinju dolaziti.

\section{Prilog 2}

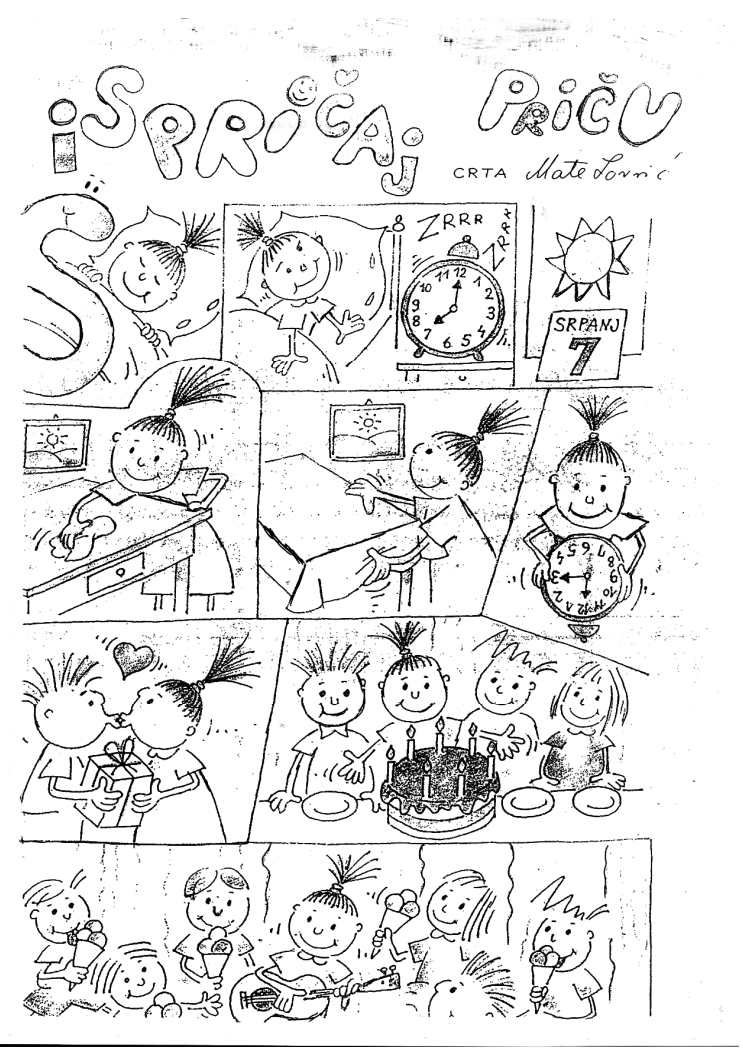




\section{Prilog 3}

\section{MOJ DAN}
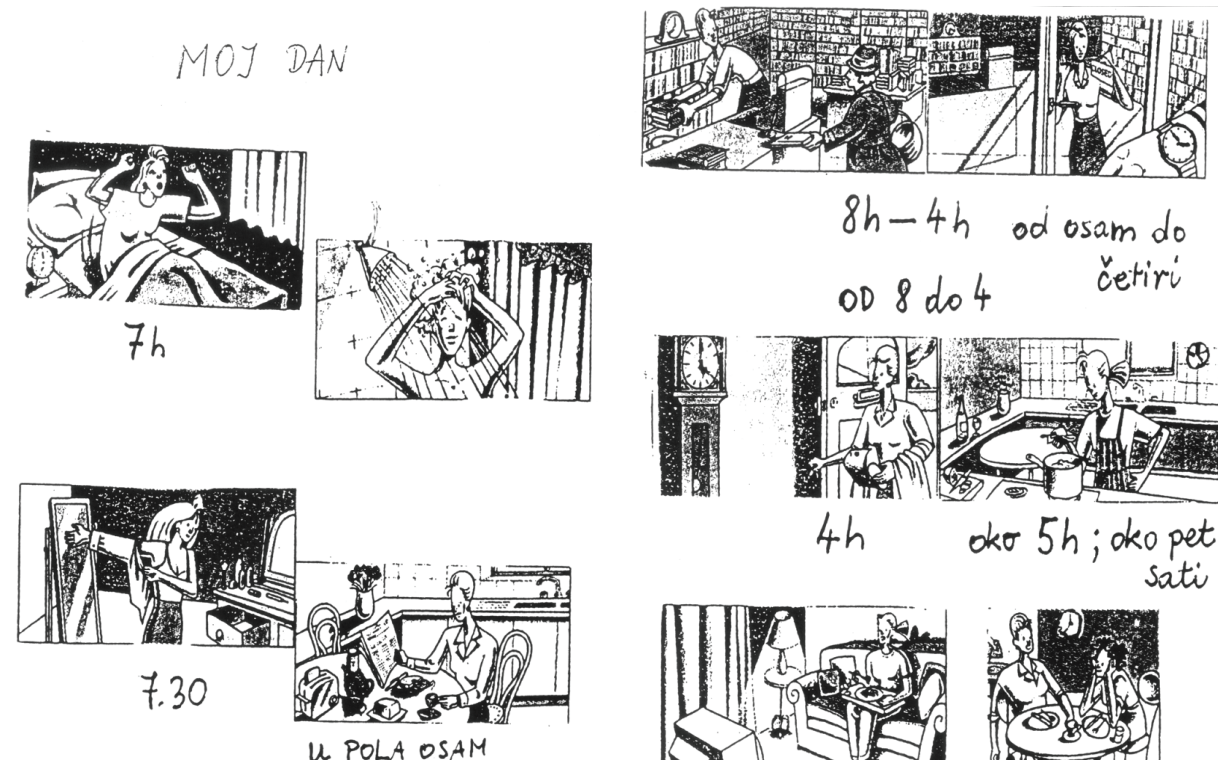

$8 h-4 h$ od osam do
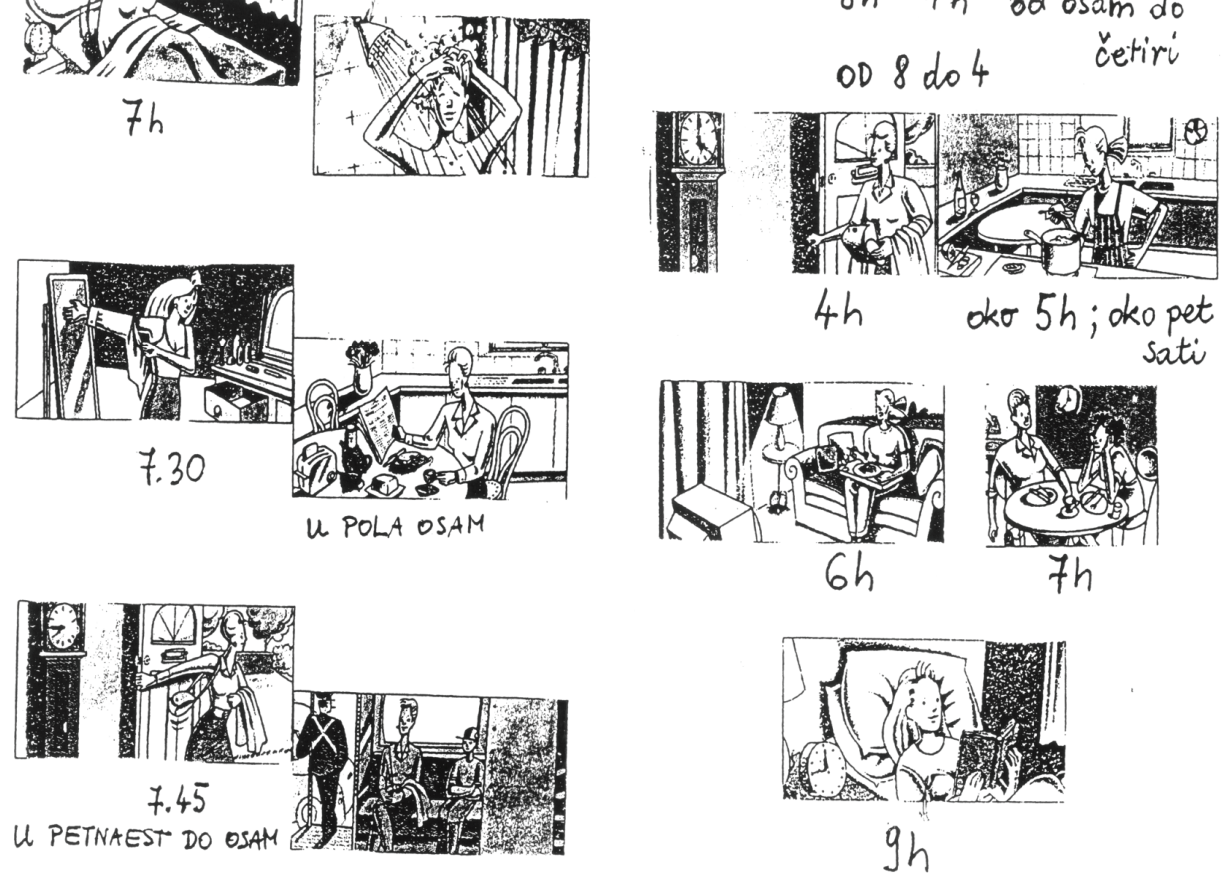
Prilog 4

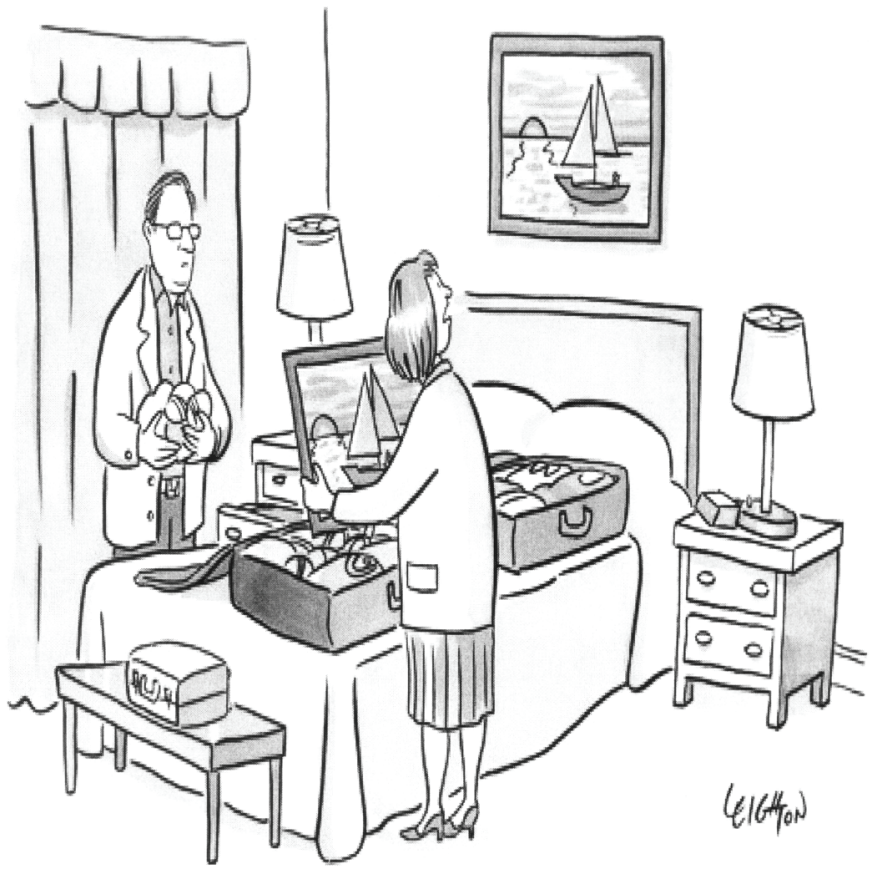




\title{
DIFFERENCES IN SPEECH ERRORS IN CROATIAN AS L2 BETWEEN BEGINNERS AND ADVANCED LEVEL
}

\begin{abstract}
The aim of this research is to investigate the similarities and differences in speech processing of Croatian as foreign language (L2), regarding the different level of language aquisition - beginners and advanced learners. Speech processing has been approached by analyzing speech errors as one of its direct overt manifestations. Variables of speech fluency have been analyzed: grammatical errors, hesitations and self-corrections. Also an attempt has been made to find out what these phenomena reveal about the psycholinguistic processes of speech production in L1 and L2. The research has been conducted among 10 native speakers of English who have studied Croatian for four months at Croaticum-Centre for Croatian as second and foreign language at the Faculty of Humanities and Social Sciences in Zagreb. They have been divided into two groups according to their proficiency level and are homogeneous in relation to their native language. The research has confirmed both hypotheses: that beginners and advanced learners of Croatian as foreign language make different types of speech errors and that beginners and advanced learners of Croatian as foreign language differ in the total number of speech errors.
\end{abstract}

Key words: speech errors, language learning, foreign language, Croatian 